TA'DIB: JURNAL PENDIDIKAN ISLAM, 25(2), 2020

Avaliable Online At: http://jurnal.radenfatah.ac.id/index.php/tadib

\title{
Modern Pesantren Tradition: Kiai's Leadership in Keeping the Tradition in the Industrial Revolution 4.0 Era
}

\author{
Apud $^{1 *}$, Akrom $^{1}$ \\ ${ }^{1}$ State Islamic University of Sultan Maulana Hasanuddin, Banten, Indonesia \\ *Corresponding Author Email: apud@ uinbanten.ac.id
}

\begin{tabular}{ll}
\hline \multicolumn{1}{c}{ ARTICLE INFO } & \multicolumn{1}{c}{ ABSTRACT } \\
\hline $\begin{array}{l}\text { Article History: } \\
\text { Received : } 30-10-2020\end{array}$ & This study aimed to describe modern pesantren tradition that \\
Revised : 23-11-2020 & focused on the traditional values, kiai's leadership in keeping \\
Accepted : 22-12-2020 & the tradition, and modern pesantren educational orientation in \\
& the industrial revolution 4.0 era. The data collection was \\
Keyword: & carried out through interviews, observation, and documentation \\
Tradition; & with multi-site research. The research sites were six modern \\
Pesantren; & pesantren which were taken from six districts or cities in \\
Industrial revolution 4.0 era. & $\begin{array}{l}\text { Banten province. The findings of the research were: Modern } \\
\text { pesantren was the daily life behavior of all its residents who }\end{array}$ \\
& were attached to five souls and motto of the pondok. The \\
& leadership of the kiai was not centralized to the role of the kiai \\
& but it was distributed to the teachers, and the kiai's role as the \\
& guardian of the modern pesantren tradition was central; the \\
& education of modern pesantren in the industrial revolution 4.0 \\
& era had experienced a shift in orientation, especially in \\
preparing qualified graduates in the digital era. The modern \\
pesantren did not only serve as the institution of tafaqquh fi al- \\
din which educated students to have noble character but also \\
prepared independent and competitive graduates in the digital \\
era.
\end{tabular}

This is an open access article under the CC-BY-SA license

How to Cite:

Apud, A., \& Akrom, A. (2020). Modern pesantren tradition: Kiai's leadership in keeping the tradition in the industrial revolution 4.0 era. Ta`dib: Jurnal Pendidikan Islam, 25(2), 136-151.

https://doi.org/10.19109/td.v25i2.6834 


\section{INTRODUCTION}

Pesantren is an old Islamic education institution in Indonesia that develops in the society and becomes genuine Islamic education institution (Yasid et al., 2018). Pesantren is tafaqquh fiddin education institution that teaches deep Islamic teachings and produces Ulama and leaders in Indonesia. In the colonial era, pesantren is an educational institution which closely related with society, then, it is not overwhelming if pesantren is rooted with society's life. It is assumed that the attendance of pesantren in the society is not only as an education institution but also as a propaganda institution and social religion.

Nowadays, pesantren need to review the orientation of pesantren and new challenges carefully (Azra, 1999). In the globalization era, according to Atmaturidi (2001) there are three pesantren's attitudes in facing modern educational system, they are (a) avoiding modern educational system; (b) integrating traditional and modern educational system, this is started from Madrasah Ibtidaiyah, Madrasah Tsanawiyah, Madrasah Aliyah, and higher education level; and (c) teaching classic books as well as general science, this is started from elementary, secondary, senior, and university level. While Yasid et al. (2018) divided pesantren into two big groups, they are traditional (salafiyah) and modern (khalafiyah) pesantren. For that reason, Dhofier (1980) mentioned the terms of salafi and khalafi pesantren.

In addition to the two types of pesantren, as stated by Yasid et al. (2018) the two types of pesantren have different characteristics. Salafiyah pesantren has characteristics as follows: pesantren tends to a kiai's hand, teaches Islamic education only, use classic books, puts forward the traditional education such as weton, bandongan and sorongan, makes kiai as best examples among ustadz and santri, and tends to communal and egalitarian lifestyle (Dhofier, 1980; Yasid et al., 2018). Meanwhile, khalafiyah pesantren has characteristics as follows: cooperative leadership, educational program oriented on religion and general science, classic and non-classic sources, modern and innovative method, personal and collegial relationship, and individual and competitive lifestyle (Yasid et al., 2018). Classis sources are classic books that had been written since many centuries ago and these books are often called as yellow books (Bruinessen, 1995). At salafiyah pesantren, religious education materials are limited to Al-Qur'an teachings and yellow books (Steenbrink, 1994). Azra (1999) explained that yellow books are written in Arabic, Malay, Java, or regional languages in Indonesia by using Arabic script which was written by the middle east and Indonesia ulama (Dahlan, 2018). Meanwhile, non-classic sources are Arabic books literature contemporary (apart from classic or yellow books).

Besides those two types, there is one of pesantren that is similar to khalafiyah pesantren that is modern pesantren which is promoted by Darussalam Gontor Pesantren in 1926. Zarkasi as cited in Muhakamurrohman (2014) defined that pesantren is as Islamic education institution which applied boarding school system, made kiai as a central figure, put mosque as spiritual activities, and arranged Islamic studies process under kiai's guidance as routine activities. Modern pesantren developed with madrasah system which uses multi-discipline approaches based on the development of era (Helmi \& Nadri, 2016).

The establishment of modern pesantren modernizes the educational system in terms of curriculum and material resources. Modern pesantren does not make kutub turots the main source in teaching and learning, but tafaqquh fi al-din is still a special characteristic in pesantren world. Abdullah Syukri, as a leader of Daarussalam Gontor Pesantren, stated that pesantren curriculum is santri's daily life for 24 hours. All santri and pesantren's caregivers must follow the regulation and discipline determined by kiai. All regulation, 
habit, and tradition at pesantren's environment are called sunnah-sunnah pesantren (pesantren's tradition). This tradition must be followed by pesantren's citizens and given punishment to the ones who break the rules.

There are many values applied in pesantren's life (Azhari, 2011; Azra, 1999; Mastuhu, 1994). Madjid (1997) as cited in Said (2011) identified that there are twelve values such as; ethnocentric, sincere devotion, wisdom, simplicity, collectivity, togetherness, guided freedom, independence, scientific center, the practice of religious teachings, and obedience with kiai. Pesantren's values make it exist until nowadays. Based on the result of research about pesantren's tradition found that every pesantren has maintained the traditional values.

Dhofier's study (1980) revealed that the successful leadership of pesantren in interpreting traditional Islamic values in public and national political space. Kusmira (2018) found that modern values at pesantren such as; pesantren's multiculturalism, academic tradition, management, and leadership and economical axis showed the readiness of pesantren in facing the economical society of ASEAN. Modern management and leadership have changed from charismatic to collegial collective leadership. It means top leadership must be based on the result of discussion at pesantren. This influenced the ability of kiai's yellow books mastery and management, coordination, funding formulating, project implementation, budget auditing, and seeing the indicators of leadership and followers. The study conducted by Helmi and Nadri (2016) about kiai's leadership in keeping pesantren's tradition at Mu'awanah Khalafi Pesantren, West Bandung revealed that the leadership at this pesantren could face th'e global challenges due to the leadership kept holding the regional values principals and al-muhafazhatu'ala al-qadimi al-salihwa al-akhzu bi al-jadidi al-aslah, namely, it kept the old tradition and accepted new challenges.

The studies above showed that the researchers put big attention to do research on pesantren's tradition, moral values, and kiai's leadership from era to era. For that reason, this study focused on deepens the pesantren's tradition up, moral values, and kiai's leadership. The gap between this study and previous related studies is modern pesantren's tradition and kiai's leadership in the industrial revolution 4.0 era. This research was important to be done since modern pesantren education was strict enough in keeping the tradition, dynamic in responding globalization, cooperative leadership, integrative religion, and general science. Therefore, the purpose of this research was to describe about moral values on modern pesantren's tradition, kiai's leadership in keeping in the tradition industrial revolution 4.0 era, and educational orientation in the industrial revolution 4.0 era.

\section{LITERATURE REVIEW}

\section{Moral Value in Keeping Modern Pesantren's Tradition}

Brumund (1857) mentioned that pesantren's tradition is part of Islamic education found in Java and Madura. Also, several western scientists were interested in researching on pesantren in Indonesia, such as Hurgronje in 1931, Berg in 1932, Greetz in 1956, Johns in 1975, and one of Indonesian's research was Djajadiningrat in 1908, in his memory during becoming a santri (Dhofier, 1980). Dhofier argued that the implementation of classic Islamic studies could be seen from the daily routine of santri and the faith of santri with kiai. However, western academics claimed that pesantren had influenced human social life, cultures, and politics in Java's villages.

The study of pesantren has got new atmosphere since 1980. Dhofier (1980) stated that pesantren's tradition in Java was one of an excited object for many academics in 
Indonesia to explore the perspective of pesantren. The classic study was not seen to be comprehensive in explaining pesantren in Indonesia. He also mentioned five main elements of pesantren's tradition were pondok, mosque, santri, classical books studies, and kiai. Mastuhu (1994) added that the role of kiai as the main figure at pesantren in comparing modern and traditional pesantren in the future in Java and Madura.

In this millennium era, the spirit of widening knowledge about pesantren is getting faster and faster. It can be seen from current studies from (Helmi \& Nadri, 2016; Kusmira, 2018; Masyhud \& Khusnurridlo, 2003; Muhakamurrohman, 2014; Takdir, 2018; Yasid et al., 2018). Takdir (2018) gave a picture of pesantren's traditional function in the globalization era. First, pesantren is as an instrument, a transformation media and revolution values for people to grow and adapt the global challenges faster based on the religion. Second, pesantren promotes ethical and traditional values.

The purpose of pesantren education is merely to enrich knowledge, moral values, spirit, simplicity, and other ethical behavior. According to Takdir (2018), the attendance of pesantren is undeniable to create an intelligent and spiritual generation. Dhofier (1980) explained that the knowledge was measured from how many books learned and who were the ulama. The amount of Arabic books that were written by ulama has been determined by pesantren's institution.

In the context of modern pesantren tradition, this study tried to refer to Helmi and Nadri's opinion. Pesantren's tradition is obedience values for all pesantren's citizens to obey the agreed rules in order pesantren must keep and develop cultural values, such as; independence, empowerment, trust, synergy, and responsibility (Helmi \& Nadri, 2016). Meanwhile, Mastuhu (1994) classified the values at pesantren as follows: first, religious values which absolute truth and ukhrowi have oriented. Second, religious values are relative, empirical, and pragmatic to solve daily life's problems. He also identified 25 variables in explaining the changes of salaf and kholaf in Java and Madura. The variables are kiai's blessings, sincerity, and praying. Meanwhile, (Nafis, 2008) identified that modern pesantren applied santri's values which were different from what (Helmi \& Nadri, 2016; Mastuhu, 1994) stated about khalafi's pesantren moral values which described in "five souls of pondok" and "motto" as a way of life for all modern pesantren's citizens. Five values that were formulated in five souls of the pondok. They are sincerity, simplicity, independence, ukhuwah Islamiyah, and freedom. Pondok's motto is virtuous, healthy, knowledgeable, and open-minded.

Table 1. Santri's Value

\begin{tabular}{cll}
\hline No & Theme & Moral Value \\
\hline 1 & Five souls of the pondok & Sincerity \\
& & Simplicity \\
& & Independence \\
& & Ukhuwah Islamiyah \\
2 & \multirow{2}{*}{ Motto of the pondok } & Freedom \\
& & Good behavior \\
& & Healthy \\
& & Knowledgeble \\
& Open-minded \\
\hline
\end{tabular}

\section{Kiai's Leadership at Modern Pesantren}

Leadership is the ability to influence, inspire, and command someone's or a group of people to reach the wanted goals (Rivai, 2007). In this leadership, there is a correlation between human, namely the wisdom of leadership affected the influence and obedience 
(Kartono, 2006). Kiai's leadership at pesantren has very strong authority. Kiai has a power to lead the pesantren fully. It can be seen that no one can influence his power except the more knowledgeable ulama than he is (Dhofier, 1980).

Mastuhu (1994) identified that kiai became the main source of knowledge and moral at that time. But as time flew so fast, kiai is not the only main source of knowledge. However, his voice still rises up at pesantren. Yasid et al. (2018) added that some leadership styles were; first, autocracy leadership with a powerful approach. Second, participative leadership - the leader is the only decision-maker. Third, democratic leadership - the leader is corporative. Fourth, free-rein leadership - subordinates have power, the leadership is unorganized and passive (Yasid et al., 2018). Fifth, bureaucratic leadership - the leader manages the handled groups fully. The sixth, diplomatic leadership - the leader gives motivation and ideas to run his or her duties (Helmi \& Nadri, 2016).

\section{Industrial Revolution 4.0 Era}

The term of 4.0 industry is from the idea about the fourth industry revolution. The existence of it offers potential and useful advantages (Prasetyo \& Sutopo, 2018). The characteristics of industrial revolution 4.0 are marked by the development of digitalization, manufacture, and logistic industry integration. It is maximized by the internet and smart engines, blended offline, and online (ICT) (Fonseca, 2018). The implementation of 4.0 industries offers advantages as well as challenges. According to Drath and Horch (2014) cited in Prasetyo \& Sutopo (2018), the challenges showed up on demographic and social aspects, unstable politics, limited human resources, natural disasters, and environmentally applied technologies.

Industrial revolution 4.0 also affected education. It supported educational institutions to use technologies, such as; E-Learning, instructional application, and self-study platform which were also appropriate with 4.0 education standard (Surani, 2019). The 4.0 educational industry must respond to the need of the industrial revolution 4.0 where a human must be creative and innovative to create new chances (Lase, 2019). For that reason, curriculum development should be done to respond to the era changes in order not to leave behind. The new curriculum must encourage students to have academic dimensions, HOTs, global-minded, and well digital literate (Lase, 2019).

\section{METHOD}

Research design is a case study using multiple sites assumption those have the same characteristics. Research with multiple sites is used to develop the theory (Bogdan \& Biklen, 1992). The research aimed to describe modern pesantren tradition in values aspect as basis of tradition, kiai's leadership maintained tradition in the industrial revolution 4.0 era, and the orientation of modern pesantren in the industrial revolution 4.0 era. A whole description of the phenomena was described and interpreted by using the descriptive qualitative method. Characteristic of the qualitative method are: 1) direct data source in a reasonable situation, 2) descriptive, 3) prioritize the process than the product or result, 4) inductive data analysis, and 5) prioritize meaning (Bogdan \& Biklen, 1992). Qualitative research is often referred toas a naturalistic research method because it is done in a natural situation (Nasution, 2003; Sugiyono, 2012). The naturalistic paradigm model has perfect qualitative characteristics (Muhadjir, 1998). Naturalistic study is technique dealing with data source directly in the natural background and is intended to collect the data (Nasution, 2003). 
The location in this research was six modern pesantren in Banten province consisting of eight regencies/cities. Several reasons why the researchers chose these locations: First, most of the founders modern pesantren were from Darussalam Gontor Pesantren and Daar el-Qolam Gintung Pesantren which had the same background of education. Second, pesantren was chosen based on location around city/regency in Banten Province to obtain data about modern pesantren tradition, kiai's leadership, and the role of kiai's leadership maintained the tradition and responded to globalization in the industrial revolution 4.0 era. Third, modern pesantren had the same tradition (sunnah) pondok and kesantrian values to have similar patterns and tradition based on the location where pesantren was. Fourth, pesantren was located around city/regency dealing with different challenge and problem, especially in the industrial revolution 4.0 era. From point of view, there may be unique treatments and varied patterns in solving challenges and problems.

The researchers applied the purposive sampling technique to select participants with certain considerations (Sugiyono, 2016). Consideration or criteria of samples in this study was people who had a lot of information about phenomenon studies, leader and administrator had worked more than 15 years. Six pesantren were used as research locations and four participants were kiai and two participants were caregivers. Some reasons why the researchers selected two administrators of pesantren: first, kiai of Daar elQolam 3 Pesantren were unable to attend and was replaced by caregivers. These participants have worked for 24 years, wrote two books about Daar elQolam Pesantren and leadership in a national magazine. Second, kiai of Al-Mizan 2 for the girl was unable to attend and was replaced by administrators, too. Participants have worked for 15 years in pesantren and completed a thesis about Modern Gontor Pesantren, had good knowledge about modern pesantren tradition and kiai's leadership.

Tabel 2. Research Site and Participants

\begin{tabular}{lcc}
\hline Site & Participant & Location \\
\hline Daarunnajah 3 Al-Mansur Pesantren & Kiai & Serang regency \\
El-Karim Pesantren & Kiai & Lebak regency \\
An-Nuqthoh Pesantren & Kiai & Tangerang City \\
An-Nawaa Pesantren & Kiai & Cilegon City \\
Daar el-Qolam 3 Pesantren & Administrator & Tangerang Regency \\
Al-Mizan 2 Putri Pesantren & Administrator & Pandeglang Regency \\
\hline
\end{tabular}

In this research, the researchers used interview, observation, and documentation. The interview was conducted with kiai and caregivers about modern pesantren tradition, kiai's leadership in keeping the tradition, and orientation of modern pesantren education in the industrial revolution 4.0 era.

To strengthen the data, the writers did observation by observing the situation that occurred at the research site to obtain actual data, synchronize, and strengthen the interview result. Through this technique, the data would be objective and contextual. Besides, the observation was strengthened by the documentation, namely collecting the data through the document, photo, or other physical data. The documentation was important as a real product in providing a real picture of the data source.

The data is processed and analyzed to speak (Surakhmad, 1980), to be meaningful and found a conclusion. The data is the result of the construction information process between researchers and participants. From the perspective of writers, the data were understood by the interpretation of participants (Nasution, 2003). In qualitative research, data analysis is conducted continuously (iteratively) and developed when the problem of research begins, data collection, and after the data collected. In the multisite case study, the 
data analysis was done through a step of grouping based on similar characteristics, conducting cross-site analysis in a site group, and conducting cross-site group analysis.

Qualitative data analysis is done through data reduction activity, data presentation, and conclusion/ verification (Miles \& Huberman, 1992). To make it easier to rediscover the data, the ways are used by giving code at field record, observation, and archival material (Miles \& Huberman, 1992). The code in this study was created to make it easier for researchers to re-track the data needed. In this study, the code was created in an abbreviation system, namely; DQ-S (Daar el-Qolam-Saeful), DN-B (DarunnajahBusthomi), AL-B (Al-Mizan-Budi), EL-S (El-Karim-Subhan), AN-Bu (An-NawaaBukhori), and NU-J (An-Nuqthoh-Juhri). Data reduction was done to review all field records through interview, observation, and extensive documentation study, the summarized about main points relating to the core of research. The information has been compiled more systematically than a summary on data reduction called data presentation or display day. The most frequent data presentation in qualitative research is from narrative text (Miles \& Huberman, 1992). Inference activity was conducted by looking for meaning, pattern, explanation, possible configuration, cause and effect, and proposition. To stabilize the result of the conclusion in this study, the writers verified through member check and triangulation were among researchers and participants held meetings to check the validity of conclusions through verification of the conclusion by researchers or review and exchange of thoughts with peers to develop an inter-subjective agreement. The activities were done to fulfill the criteria of credibility, transferability, dependability, and conformability.

\section{FINDINGS}

\section{Values in Keeping Modern Pesantren Tradition in Banten Province}

Based on data analysis through the interview, observation, and documentation, it was found values in keeping modern pesantren tradition. Modern pesantren tradition is based on inherent values and is practiced in daily life at pesantren. Theme and code are described in the following table 3.

Table 3. Theme and Code for Values in Keeping Modern Pesantren Tradition

\begin{tabular}{|c|c|}
\hline Theme & Code \\
\hline Modern pesantren tradition & $\begin{array}{l}\text { a. Daily habit in pesantren is often referred to as sunnah. } \\
\text { Habituation is done by strict enforcement. } \\
\text { b. Regular habituation in daily routine and extracurricular activity } \\
\text { is considered as tradition in modern pesantren. } \\
\text { c. The tradition has long been done from generation to } \\
\text { generation. To keep the tradition, pesantren follows the rule } \\
\text { "al-muhafadzah ala al-qadim al-solih wa al-akhdzu bi al-jadidi } \\
\text { al-aslah" (following old tradition and accepting new tradition). } \\
\text { d. New tradition does not exist in modern pesantren but it has } \\
\text { already existed in traditional pesantrenthen taken and } \\
\text { practiced. }\end{array}$ \\
\hline Values in keeping the tradition & $\begin{array}{l}\text { a. Life in pesantren is based on five souls and motto of pondok. } \\
\text { b. Five souls pondok are added with two souls to become seven } \\
\text { souls pondok. } \\
\text { c. The implementation of pesantren values is based on five souls } \\
\text { and motto ofthe pondok and is done by adding ten characters } \\
\text { for santri. } \\
\text { d. Five souls and motto of thepondok are applied in pesantren } \\
\text { daily life. }\end{array}$ \\
\hline
\end{tabular}


e. Describing five souls and motto of the pondok in the activity.

f. Five souls and motto of the pondok are implemented in enforcing seven habits.

The explanation of theme and code in Table 3 is as follows:

\section{Modern Pesantren Tradition}

Based on an interview with caregivers in pondok, pesantren tradition was done by behavior and habits which occurred for 24 hours in pesantren and enforced strictly. For example, as stated by participants in pesantren "Habituation and discipline life, such as waking up early, sleeping at night, praying, eating, entering class, reciting Al-Qur'an, and other activities are life cycle and is named as sunnah in pondok" (DN-B, Saturday, March 7, 2020). Regular habituation is in daily life and extracurricular activity is considered as part of keeping tradition in modern pesantren. As stated by other participants "Academic and non-academic activities became the main objective for vision and mission in pesantren and cannot be changed for good moral" (DQ-S, Sunday, March 15, 2020).

Habituation has long been done from generation to generation. The tradition has been attached, maintained, preserved or even strengthened by the cultural values of its society. To keep the tradition, pesantren follows rule "Al-muhafadzah ala al-qadim al-solih wa alakhdzu bi al-jadidi al-aslah" (following old tradition and accepting new tradition). The actualization of the rule includes doing good habits in the community then adopted and adapted in modern pesantren environment. As stated by the participant "Actualization of the rule can be seen from manaqiban, marhabanan, reading, and kutub turots activity is commonly done in traditional pesantren although it is in a limited scale, the others are one of the indicators in modern pesantrento adapt and adopt new things in the environment" (EL-S, Saturday, March 14, 2020).

\section{Values in Keeping the Tradition}

Modern pesantren tradition is applied and practiced consistentlyin daily life. The tradition is maintained by keeping values for daily life in pesantren. From the result of the interview, values in keeping pesantren tradition were based on five souls and motto of the pondok. One of the participants states "Implementation of values is based on five souls and motto in pondok and the values of life are certainly inseparable from five souls and motto" (AL-B, Sunday, March 8, 2020). The traditional values must be a spirit and reference in every movement and activity inside and outside pesantren.

Five souls are formulated through the values of sincerity, simplicity, independence, ukhuwah islamiyyah, and freedom. While, the motto in pondok are virtuous, healthy body, knowledgeable, and free-thinking. The other participants added two souls and seven souls, as stated "Instilling the values of life in pesantren is based on soul and motto in pondok called the five souls and the motto in pondok, that is the basis for us, and we add two souls so that it becomes seven souls, namely simplicity, sincerity, independence, ukhuwah Islamiyah, freedom, honesty and patience. The five souls have collaborated with two souls namely patient and honest souls" (EL-S, Saturday, March 14, 2020). The other participants add the value of character. In addition, namely ten characters and stated by one of the participants "Gontor Pesantren students are four souls, if we add a kind of slogan called al-muwashofaat al-asyroh, and ten characters must be owned An-Nawaa students" (AN-B, Saturday, March 21, 2020).

In general, all modern pesantren in Banten province make five souls and motto in pondok as values in keeping and is described all activities although there are some unique 
things in accordance with the location and environmental condition where pesantren is. One of the participants conveys "Applying values of life is based on motto and five souls" (DQ-S, Sunday, March 15, 2020). Meanwhile the others reveals "Actually, all modern pesantren traditions are same, but modern pesantren has its own specialty and gives chance to students to be free, virtuous, and it is just description" (NU-J, Sunday, March 22, 2020). This was strengthened of statement by other participants "Enforcing discipline experience in motto pesantren "Five souls and seven habits" and the values are in five souls and seven habits and relates to be discipline and sunnah" (DN-B, Saturday, March 7, 2020).

\section{Kiai's Leadership in Modern Pesantren in Keeping the Tradition in Banten Province}

Based of result of interview and observation, it was found that kiai had a central position in keeping the tradition in industrial revolution 4.0 era. Kiai always keeps pesantren tradition by following rule al-muhafadatu ala al-qadim as-saleh wa al-akhdu bi al-jadid al-aslah (following old tradition and accepting new tradition). The theme and code are described in following table 4.

Table 4. Theme and Code of Kiai's Leadership in Keeping the Tradition in the Industrial Revolution 4.0 Era

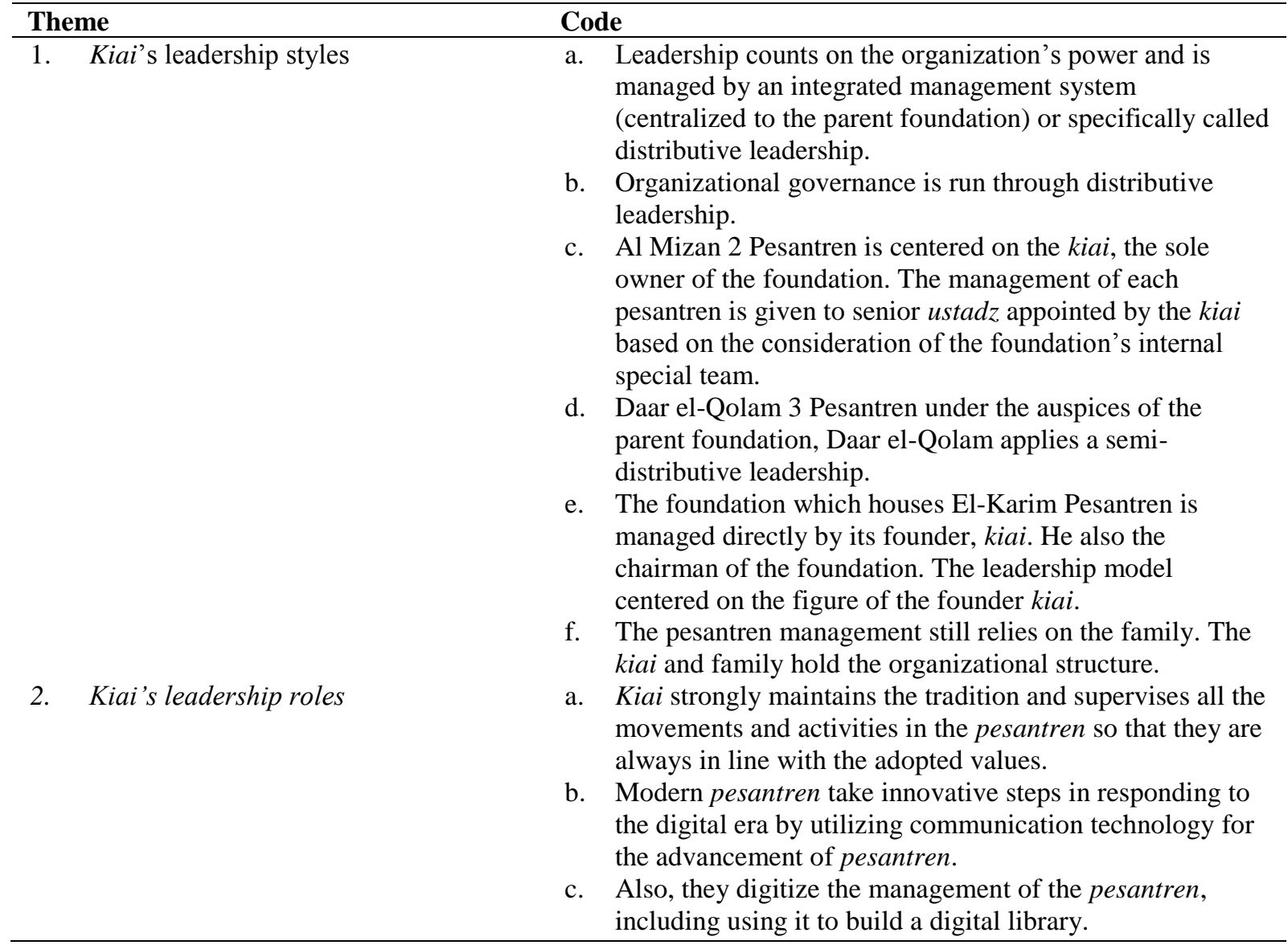

The explanation of theme and code in Table 4 is as follows:

\section{Kiai's Leadership Styles}

Based on the results of observations and interviews, there were differences between the kiai's leadership style in traditional and modern pesantren. The leadership style of kiai 
in traditional pesantren is charisma, kiai-centered, and hereditary leadership. Meanwhile, the leadership style in modern pesantren is distributive and diverse. It rests on the organization's power and is managed by an integrated management system. As stated by one of the participants, "In our place, I have no relationship or family lineage with the owner of the foundation. In this case, it is more structural. We decide something together even though you have suggestions sometimes I do not agree with your opinion so that the decision is up to me. Next, the execution will be in each zone" (DN-B, Saturday, March 7, 2020).

Parenting in modern pesantren is not so centralized to the character of the kiai, but is more emitted in the ustadz/ustadzah who contact with the santri directly. Likewise, organizational governance tends to be more systematic, especially in strategic decisionmaking that is not simply taken over by kiai. Kiai, the sole owner of the pesantren, actually has absolute authority over the pesantren. However, the management of the pesantren is distributed to lower levels. As stated by the participants, "So, the priority is on the leader. The kiai does not evaluate based on the results of his own thoughts only, but he has trusted people in this Al-Mizan" (AL-B, Sunday, March 8, 2020).

There are three levels of leadership in the foundations that house several pesantren: top, middle, and unit levels. As stated by the participant, "Daar el-Qolam 3 Pesantren under the auspices of the main foundation Daar el-Qolam applies semi-distributive leadership. There are three levels of leadership in this pesantren: (1) the kiai is the leader of the foundation, (2) the leader of the pesantren is at the managerial level per units such as Daar el-Qolam 1, 2, and 3, and (3) the leaders are in field care management" (DQ-S, Sunday, March 15, 2020). Some modern pesantren also found a leadership style that was still kiai-centered in decision making. Even though there were a periodic evaluation mechanism and a special team that considered the pesantren owner, the final decision rests with the kiai as the pesantren owner. Pesantren caregivers stated that "The organization of our pesantren is still simple; the communication channel is santri asatidz, then the leader of the boarding house. For certain urgent matters, the santri go directly to the leader" (EL-S, Saturday, March 14, 2020). Moreover, the kiai himself still made the programs. "Yes, I did it myself, particularly the work programs" (AN-B, Saturday, March 21, 2020).

\section{Kiai’s Leadership Roles}

The kiai in modern pesantren is intensely concerned with maintaining the values embraced in all pesantren activities. As stated by a participant who said that "The kiai in the pesantren really maintains the tradition of the pesantren and always oversees all the movements and activities of the pesantren so that they are always in line with the values being held. If things are contrary to these values, those are prohibitions" (DQ-S, Sunday, March 15, 2020). On the other hand, the kiai always tries to respond to the changes of the times, including the changes that occurred in the revolution 4.0 era by utilizing digital technology for educational activities. As explained by participants, "Digital technology is used for the learning process (online learning), online administration and payment, online admissions and tests of new students, promotion, and publication of pesantren through social media, and others" (EL-S, Saturday, March 14, 2020). The digital era has also responded by developing digital libraries. As stated by one of the participants, "Pesantren also respond to this digital era by digitizing the management of the pesantren to use it in building digital libraries" (NU-J, Sunday, March 22, 2020). 


\section{Modern Pesantren Educational Orientation in the Industrial Revolution 4.0 Era in Banten Province}

From the results of data analysis through interviews and observations, it was found that the industrial revolution 4.0 had an impact on the emergence of a new orientation of modern pesantren education, more specifically modern pesantren trying to respond to globalization. The themes and codes obtained from the results of the analysis are described in table 5 below:

Table 5. Theme and Code of Modern Pesantren Educational Orientation in the Industrial Revolution 4.0 Era

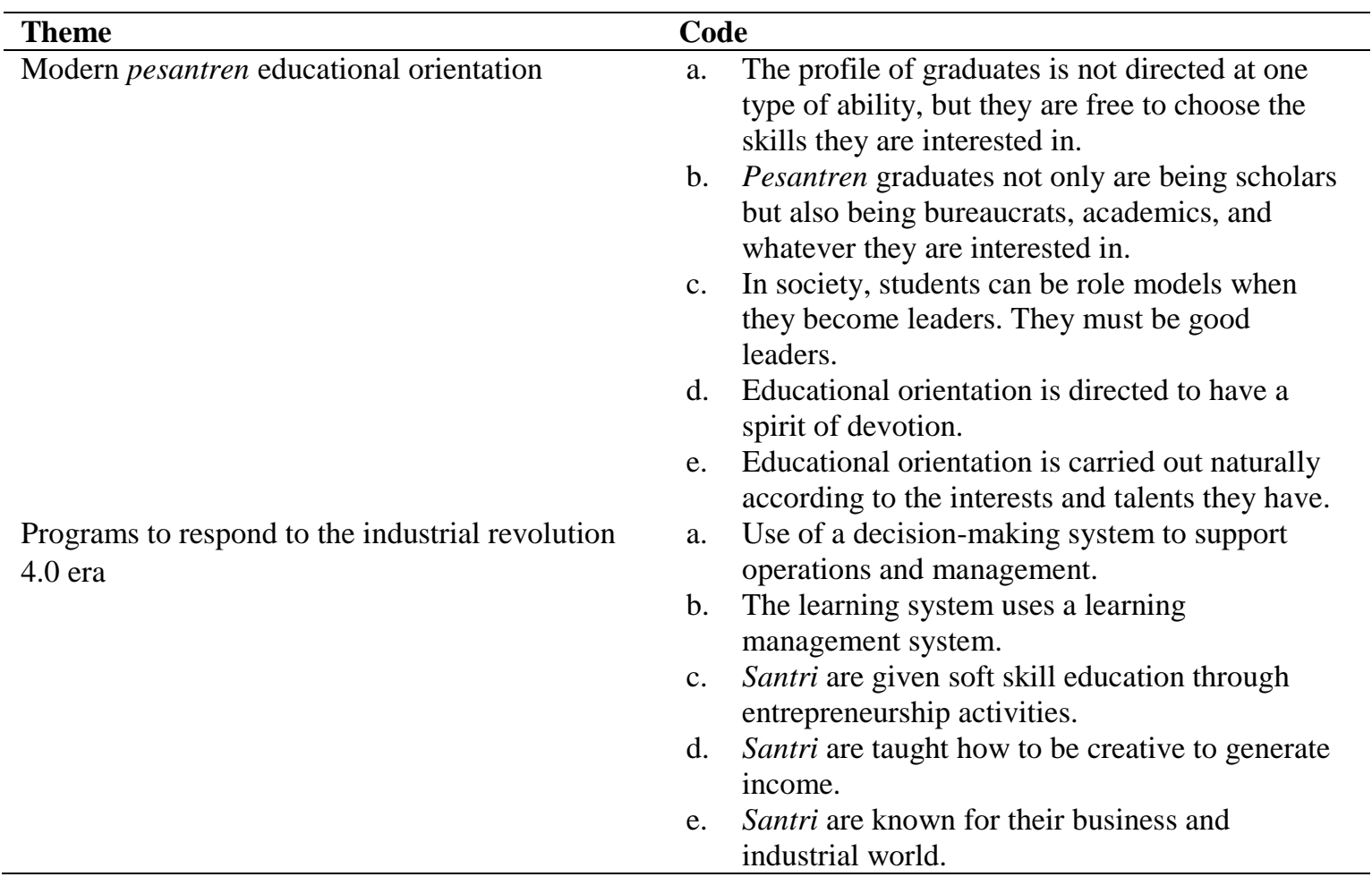

The explanation of theme and code in Table 5 is as follows:

\section{Modern Pesantren Education Orientation}

From the results of interviews and observations, it was found that the orientation of pesantren education was not only focused on graduates who mastered the science of religion but also they were prepared to be able to compete in mastering other fields. Pesantren gave graduates the freedom to choose. As stated by one participant, "Teaching may change, but education may not change. The curriculum may change, but morals may not change. We continue to make pesantren as tafaqquh fi al-din institutions that educate santri to have noble morals and also prepare graduates who can be independent and competitive in today's digital era" (EL-S, Saturday, March 14, 2020). There are pesantren that orient graduates with a minimum target of becoming teachers, "Actually our target is at least to be teachers, we hope to become teachers. If they cannot teach, at least they can teach for themselves" (AL-B, Sunday, March 8, 2020). Another pesantren orient their graduates towards the formation of a spirit of devotion. Santriis always trained to be sincere and lillahi ta'ala in their service, "Actually the orientation is express, which we usually throw at the children. There are no other special goals, like vocational high school 
students, we always practice lillahi ta'ala. Then, if they want to go to nationally, we will support it" (AN-B, Saturday, March 21, 2020).

\section{Program to Respond Industrial Revolution 4.0 Era}

From the interviews and observations conducted, it was found that the pesantren made programs to improve soft skills, increase interest and talent, digitize management, and management of the pesantren. First, the soft skill improvement program for students through the cultivation of an entrepreneurial mentality, "All the activities of this pesantren in serving santri are managed by teachers and students. Santri shop by themselves, then they make their own financial reports under the guidance of their teachers. They are trained honestly on what the sales value is which must be deposited" (EL-S, Saturday, March 14,2020). The pesantren also trained santri to develop their interests and talents, such as gardening activities and creating digital works. As the participant said, "Every student must be equipped with expertise in the digital field, so the pesantren provides a standard laboratory with expert teachers in the IT field. And at our pesantren, santri must learn it. There are santri who can autoCAD, even make short films. Yesterday there was a kinemaster training from teachers, then learning is through that basis, just reciting books is already using it, too" (EL-S, Saturday, March 14, 2020). Through the development of students' interests and talents, students are also taught to be able to produce products and marketed in the pesantren environment, "Students are taught how to be creative to generate income throughhandicrafts of making screen printing,making short storiesthen printing and marketing them" (AL-B, Sunday, March 8, 2020). To broaden their knowledge, students are also equipped with empirical experiences to get to know the business world and the industrial world. As the participant stated, "We have been cooperating with several factories. We are often called upon to give the material even students are asked to appear, to get to know the world of factories through this collaboration" (AN-B, Saturday, March 21, 2020).

Besides, modern pesantren have also improved the governance system and management of the digitalization program institutions. The use of a system with this technological device certainly facilitates monitoring and evaluation in several aspects of pesantren management, especially in terms of orderly administration and documentation which often become obstacles when using conventional methods. As stated by one participant, "If we actually already use the DSS system, the smart system, it connects the three lines of care, education, and finance" (DN-B, Saturday, March 7, 2020). The use of digital technology is also carried out in classrooms; the learning process is carried out by utilizing digital sources that allow students to easily access various learning sources and the use of online learning media, especially during this pandemic. As stated by participants, "We are in this Covid-19 pandemic using a learning management system (LMS) application in the learning process, where students learn from home online" (DQS, Sunday, March 15, 2020).

\section{DISCUSSION}

The results of research on six modern Islamic boarding schools in Banten province show that modern pesantren have a tradition that has been inherent and maintained, preserved, or even strengthened by the cultural values of the community in the pesantren environment. This tradition is preserved in the form of activities to habituate the behavior of daily life in pesantren with a discipline known as "Sunnah Pondok". Patterned and regular habits in daily routine and additional extra-curricular activities are considered as 
part of maintaining and caring for traditions in this modern pesantren. Various "sunnah" or habitual behavior of daily life in pesantren are passed down from generation to generation. Pesantren, as an Islamic educational institution, has a distinctive tradition and revealed in the classical study of Brumund (1857). Dhofier (1980) reinforced the description of the pesantren tradition summarized in the results of his research on the main elements of the pesantren, namely: dormitories, students, mosques, classical books, and kiai. Dhofier found a tradition in the life sphere of the santri in the form of absolute obedience without reserves to kiai, and in some cases, they told about basic lessons about classical Islamic books.

This symbol of obedience is a traditional value that is rooted in the pesantren environment. With its five souls and motto of the pondok, modern pesantren builds the foundation of tradition, lays down basic values that serve as a reference and binder, and at the same time become the philosophy adopted. The practice of traditional values instilled in life is a reflection of the five souls and motto of the pondok. Past studies confirm these findings, such as the results of research by Helmi and Nadri (2016) at Mu'awwanah Modern Pesantren, West Bandung, which found the values that bind the pesantren tradition, namely: sincerity, independence, and obedience. These three values serve as a shield and capital for pesantren in adapting and facing global change.

The kiai, as guardians of the pesantren tradition, have a significant role in leading and caring for the tradition of the pesantren. The difference between the kiai's leadership in traditional and modern pesantren lies in the leadership pattern. The leadership of the kiai in modern pesantren is not so centralized to the kiai's character, but it is more emitted by the ustadz/ustadzah who is in direct contact with the students. Likewise, organizational governance tends to be more systematic, especially in decision-making strategic, which is not simply taken over by the highest leadership of the organization or kiai. This is a form of moderatism in managerial and leadership. In today's context, there has been a shift in the kiai's leadership from charismatic to collegial collective leadership (Kusmira, 2018). This has become the capital for modern Islamic boarding schools in responding to today's global challenges, such as in the face of the ASEAN Economic Community (AEC) era. Kusmira in his study offers some moderate values of pesantren as the practice of the almuhafadatu principle ala al-qadim as-salehwa al-akhdu bi al-jadid al-aslah (maintaining good old traditions and making new and better ones), namely multiculturalism pesantren, pesantren academic traditions, pesantren managerial and leadership, and pesantren economic axis (Kusmira, 2018).

Dhofier's study as a classic study that previously analyzed pesantren in Indonesia confirmed this finding. The kiai in pesantren, although very synonymous with traditional Islamic ideas, have room for future development. The kiai has succeeded in adapting traditional interpretations of Islam for life in new dimensions both in the social and political fields. The kiai as a group is well represented in the executive and legislative bodies of the Indonesian government (Dhofier, 1980). The kiai's ability to care for traditions in the era of industrial revolution 4.0 in the life of the pesantren shows that kiai's leadership is very central in the various changes that occur in the pesantren environment. The studies of (Dhofier, 1980; Kusmira, 2018; Mastuhu, 1994) reinforce this finding that the occurrence of fundamental changes and transformations, especially in the application of the curriculum in the face of the next era, was predicted by several reasons, namely: first, recently almost all pesantren organizing types of formal education such as madrasah, public schools, and universities. Second, students need clear expertise in line with the changing needs of the community. Third, there is a tendency for students to be more 
interested in studying science and technology. Fourth, the classy pesantren model was introduced. Fifth, there is a fee for education, including Islamic boarding schools (Kusmira, 2018). This is also driven by the objectives of pesantren education as conveyed by Nafi, namely: forming a personality that has been exemplified by Rasulullah Saw; strengthening the competence of students through four levels of objectives; namely the initial goal, intermediate goal, the main goal and final goal; and the dissemination of knowledge through amar ma' ruf nahyi munkar by producing preachers and participating in community empowerment (Takdir, 2018).

The era of the industrial revolution 4.0 certainly affects the orientation of education in modern pesantren, especially in preparing graduates who are of good quality and who can face the challenges of this digital era. Santri not only learn about religious knowledge but also learn about general sciences by which they can live independently and be competitive. The change in the educational orientation of the pesantren demands reform of the pesantren which according to Yasid et al. (2018) can be done with the following steps, namely: first, the renewal of learning methods known as sorogan, bandungan, halaqoh, and memorization is shifted or combined with modern learning methods and students are also given skills education so that students have the skills to be entrepreneurial. Second, curriculum reform combines religious and general content in a balanced and proportionate manner. Third, updating the evaluation system allows students to continue their education to the next level. And fourth is the renewal of the management and leadership system so that it allows all elements to be involved in decision-making. The discussion section contains: 1) Meaning/interpretation of the results of data analysis; 2) compare with the results of previous research findings; 3 ) integrating research results into an established pool of knowledge; 4) preparation of new theories or modification of existing theories and 5) Implications of research results.

\section{CONCLUSION}

Based on the results of the study, the tradition of modern pesantren can be seen from the daily life behavior of all pesantren residents while in their environment. This tradition has been attached, preserved, preserved, or even strengthened by the cultural values of the people. The traditional values of modern pesantren are instilled and practiced in istiqomah in daily activities. These values become the basic values that determine the style and color of the various life activities of the pesantren residents which are formulated in the form of the five souls and motto of the pondok. The kiai as guardians of the pesantren tradition plays a very important role in leading and caring for the tradition of the pesantren. The leadership of the kiai in modern pesantren is not centralized to the character of the kiai but is distributed to the asatidz who are directly related to the students. Likewise with organizational governance tends to be more systematic, especially in strategic decision making which is not simply taken over by the highest leadership of the organization or kiai. However, the kiai's role as the guardian of the pesantren tradition remains central. The educational orientation modern pesantren in the industrial revolution 4.0 era has experienced a shift, especially in preparing graduates who are of good quality and can face the challenges of this digital era. The orientation of modern pesantren education is not only tafaqquh fi al-din which educates students to have noble morals but also prepares independent and competitive graduates in today's digital era. 


\section{REFERENCES}

Atmaturidi, A. (2001). Sistem pengelolaan pesantren. Yogyakarta: Universitas Negeri Yogyakarta.

Azhari, H. (2011). Evolusi dunia pesantren: Dari Gintung ke Rangkasbitung. Ciputat: Fikra Publishing.

Azra, A. (1999). Pendidikan Islam: Tradisi dan modernisasi menuju millennium baru. Jakarta: Logos Wacana Ilmu.

Bogdan, R. C., \& Biklen, S. K. (1992). Qualitative research for education: An introduction to theory and method. Boston: Allyn and Bacon.

Bruinessen, M. V. (1995). Kitab kuning: Pesantren dan tarekat. Bandung: Mizan.

Dahlan, Z. (2018). Khazanah kitab kuning: Membangun sebuah apresiasi kritis. ANSIRU PAI: Pengembangan Profesi Guru Pendidikan Agama Islam, 2(1), 1-19.

Dhofier, Z. (1980). The pesantren tradition: A study of the role of the kiai in the maintenance of the traditional ideology of Islam in Java. Canberra: The Australian National University Canberra Act 0200.

Fonseca, L. M. (2018). Industry 4.0 and the digital society: Concepts, dimensions, and envisioned benefits. Sciendo, 12(1), 386-397.

Helmi, A., \& Nadri, T. (2016). Kepemimpinan kyai dalam menjaga tradisi pesantren (studi deskriptif di Pondok Pesantren Khalafi Al-Mu'awanah kabupaten Bandung Barat). Ta'dib: Jurnal Pendidikan Islam, 5(1), 9-18.

Kartono, K. (2006). Pemimpin dan kepemimpinan. Jakarta: PT Raja Grafindo Persada.

Kusmira, D. (2018). Moderatisme pendidikan pesantren di Indonesia: Kajian modalitas pesantren menuju masyarakat ekonomi ASEAN. Jurnal Ilmiah Pesantren, 4(4), $527-$ 542.

Lase, D. (2019). Pendidikan di era revolusi industri. Sundermann: Jurnal Ilmiah Teologi, Pendidikan, Sains, Humaniora, Dan Kebudayaa, 1(1), $29-43$.

Mastuhu, M. (1994). Dinamika system pendidikan pesantren. Jakarta: Seri INIS XX.

Masyhud, M. S., \& Khusnurridlo, M. (2003). Manajemen pondok pesantren. Jakarta: Diva Pustaka.

Miles, M. B., \& Huberman, A. M. (1992). Analisis data kualitatif. Jakarta: UI-PRESS.

Muhakamurrohman, A. (2014). Pesantren: Santri, kiai, dan tradisi. Jurnal Ibda, 12(2), 109-118.

Nafis, M. W. (2008). Pesantren Daar el-Qolam menjawab tantangan zaman: Biografi kepemimpinan K.H. Ahmad Rifa 'i Arief. Tangerang: Daar el-Qolam Press.

Nasution, S. (2003). Metode penelitian naturalistic kualitatif. Bandung: Tarsito.

Prasetyo, H., \& Sutopo, W. (2018). Industri 4.0: Telaah klasifikasi aspek dan arah perkembangan riset. Jurnal Teknik Industri, 13(1), 17-26.

Rivai, V. (2007). Kepemimpinan dan perilaku organisasi. Jakarta: PT. Raja Grafindo.

Said, H. A. (2011). Meneguhkan kembali tradisi pesantren di nusantara. Ibda: Jurnal Kajian Islam Dan Budaya, 9(2), 178-193.

Steenbrink, K. A. (1994). Pesantren, madrasah, sekolah: Pendidikan Islam dalam kurun modern. Jakarta: LP3ES.

Sugiyono, S. (2012). Metode penelitian pendidikan pendekatan kulitatif dan kuantitatif. Bandung: Alfabeta.

Sugiyono, S. (2016). Metode penelitian kombinasi (mixed methods). Bandung: Alfabeta.

Surakhmad, W. (1980). Pengantar penelitian dasar: Metode dan teknik. Tarsito: Bandung.

Surani, D. (2019). Studi literatur: Peran teknologi pendidikan dalam pendidikan 4.0. Prosiding Seminar Nasional Pendidikan FKIP, 456-469. 
Takdir, M. (2018). Modernisasi kurikulum: Konsep dan metode antroposentris. Yogyakarta: IRCiSoD.

Yasid, A., Nahe'i, N., Hadori, M., Alimin, M., Arfandi, A., Mighfar, S., ... Hariyanto. (2018). Paradigma baru pesantren: Menuju pendidikan Islam transformatif. Yogyakarta: IRCiSoD. 